International Journal of Food Science, Nutrition and Dietetics (IJFS)

ISSN 2326-3350

\title{
Chemical Composition And Nutritional Evaluation Of Leea Guineensis Seed
}

Research Article

Ajiboye B.O ${ }^{1 *}$ Oso A.O ${ }^{1}$, Kobomoje O.S

${ }^{1}$ Department of Chemical Sciences, Afe Babalola University, Ado-Ekiti, Nigeria.

${ }^{2}$ Department of Biological Sciences, Afe Babalola University, Ado-Ekiti, Nigeria.

\section{Abstract}

The proximate composition, minerals, fatty acids and amino acids profile of Leea guineensis seeds were investigated. The results of the proximate analysis revealed that Leea guineensis seeds have crude protein of $22.30 \pm 0.45 \%$, crude fiber of $14.38 \pm 1.20 \%$ and ash of $6.96 \pm 0.16 \%$. The results also shows that Leea guineensis seeds is a good sources of dietary minerals especially potassium, phosphorus, magnesium, manganese and copper. Fatty acids profile of the seeds revealed that the seed lipids contained higher concentration of linoleic acid, oleic acid and palmitic acid. Also, amino acids profile of Leea guineensis seeds showed that it essential amino acids such as threonine, valine, isoleucine, leucne, tyrosine, phenylalanine and histidine. Leea guineensis seed is therefore considered to be a good source of essential nutrients that would be useful for both animal and human being

Key Words: Leea guineensis; Proximate Analysis; Mineral Profile; Fatty Acid Profile; Amino Acids Profile

\section{*Corresponding Author:}

Ajiboye B.O

Department of Chemical Sciences, Afe Babalola University, Ado-Ekiti, Nigeria.

Tel: +2347039027683

E-mail: bash1428@yahoo.co.uk

Received: February 06,2014

Accepted: February 20, 2014

Published: February 24, 2014

Citation: Ajiboye B.O , Oso A.O, Kobomoje O.S (2014) Chemical Composition and Nutritional Evaluation of Leea Guineensis Seed. Int J Food Sci Nutr Diet. 3(2), 94-98. doi: http://dx.doi.org/10.19070/23263350-1400019

Copyright: Ajiboye B.O ${ }^{\circ}$ 2014. This is an open-access article distributed under the terms of the Creative Commons Attribution License, which permits unrestricted use, distribution and reproduction in any medium, provided the original author and source are credited.

\section{Introduction}

Leea is a genus of plants that are distributed throughout Northern and Eastern Australia, New Guinea, South and Southeast Asia and parts of Africa. The Botanical name is Leea guineensis, belongs to subfamily Vitaceae and family Leeaceae with the local name(s) Alugbokita in Yoruba Language and Okatakyi in Twi Language [17]. It has an English name called Red tree vine or Hansid-hapan. Leea contains approximately 70 species. It is an evergreen shrub or small tree native to tropical Africa. Leea's are vigorous growers and need quite a lot of space. The light green new growth is quite a contrast to the dark green foliage. Leea guineensis is propagated by stem cutting or by seed. Seed germinate in $14-21$ days at $70^{\circ} \mathrm{F}$ and it can grow up to $20 \mathrm{ft}$ in high [17]. The plant is native to moist, intermediate temperate zones in tropical Africa including Cote dIvoire, Liberia, Sierra Leone, Ghana, Cameroon and Nigeria.

The plant is used in the treatment of enlarged spleen in children, pregnancy detection, purgative, toothache, gonorrhea, general weakness, skin lesions, skin rash, ulcer, diarrhea, dysentery, as a diuretic; oral treatments, as a pain-killer, paralysis, epileptic fits (juice of fresh leaves used as an enema), convulsions, spasm, stomach troubles, herpes and boils. It also posse fungistatic and bacteriostatic[14].Therefore, the aim of this work is to assess the nutritional composition of Leea guineensis seeds

\section{Materials and Methods}

Samples of Leea guineensis seeds were obtained from evergreen forest in Osin-Ekiti, Ekiti State, Nigeria. The seeds were dried in an oven at $50^{\circ} \mathrm{C}$, these were then milled using a local grinding machine and the powder were then used for the analyses

\section{Proximate analysis}

The crude protein, lipids, fiber and ash were determined in triplicate using the methods describes by AOAC [1,31], while the carbohydrate content was determined by difference method (calculated by subtracting the sum of crude protein, crude fat, crude fiber and ash from total dry matter content). Also, the concentration of the milled samples was determined by the micro-kjeldahl method and multiplied by 6.25 to estimate the crude protein content. The lipid content was estimated by the usual procedure of continuously extracting the fat content of the sample using continuous extracting the fat content of the sample using petroleum ether $\left(40-60^{\circ} \mathrm{C}\right)$ as a solvent in a soxhlet extractor. Crude fiber was determined by defatting a known weight of the sample with petroleum ether. The defatted sample was boiled under reflux with $\mathrm{H}_{2} \mathrm{SO}_{4}$, filtered and washed with boiling water till the filtrates were no longer acidic. Then, the residue was boiled with $\mathrm{NaOH}$, filtered and washed with boiling water till the filtrates were no longer basic. The residue was dried in an oven at $100^{\circ} \mathrm{C}$, cooled in a desiccator and weighed. This was finally incinerated in a muffle furnace at about $600^{\circ} \mathrm{C}$, cooled in a desiccator and weighed. In addition, the ash content was estimated by heating a known weight of the sample inside a pre-weighted porcelain crucible in a muffle furnace at $600^{\circ} \mathrm{C}$.

\section{Mineral determination}


$0.2 \mathrm{~g}$ of the ashed samples was weighed into the precleaned borosilicate $250 \mathrm{ml}$ capacity beaker for digestion. $30 \mathrm{ml}$ of the nitric acid was added into the weighed sample in the beaker. The sample with the digesting solvent was placed on the hot plate for digestion in the fume cupboard and allowed to cool. Also, another $20 \mathrm{ml}$ of the digesting solvent was added and digested further in the fume cupboard. The mixture was then allowed to cool at room temperature. This was filtered into $250 \mathrm{ml}$ standard volumetric capacity borosilicate container, and made up to the mark level with deionized water. Furthermore, the digested sample was sub-sampled into pre-cleaned borosilicate glass containers for Atomic absorption spectrophotometer [1,31]

\section{Fatty acid determination}

$50 \mathrm{mg}$ of the extracted fat content of the sample was saponified for five minutes at $95^{\circ} \mathrm{C}$ with $3.4 \mathrm{ml}$ of the $0.5 \mathrm{M} \mathrm{KOH}$ in dry methanol. The mixture was neutralized by using $0.7 \mathrm{M} \mathrm{HCl} .3 \mathrm{ml}$ of the $14 \%$ boron triflouride in methanol was added. The mixture was heated for 5 minutes at the temperature of $90^{\circ} \mathrm{C}$ to achieve complete methylation process. The fatty acid methyl esters were thrice extracted from the mixture with redistilled n-hexane. The content was concentrated to $1 \mathrm{ml}$ for gas chromatography analysis and $1 \mu \mathrm{l}$ was injected into the injection port of gas chromatography $[1,31]$.

\section{Amino acid extraction}

The sample of $10.0 \mathrm{~g}$ was (dried and pulverized sample was made to be free of water by ensuring constant weight for a period of time in the laboratory) weighed into the $250 \mathrm{ml}$ conical flask capacity. The sample was deffated by extracting the fat content of the sample with $30 \mathrm{ml}$ of the petroleum spirit three times with soxhlet that was equipped with thimble. The sample was hydrolyzed three times for complete hydrolysis. Then the amino acid content of the sample was recovered by extracting with $30 \mathrm{ml}$ of the dichloro methane three times before concentrating to $1.0 \mathrm{ml}$. The concentrated extract was derivatised for volatility that is suitable for gas chromatography $[1,31]$.

\section{Results}

Table 1 shows the result of proximate analyses of the Leea guineensis seed with $22.30 \pm 0.42 \%$ of protein. It has carbohydrate in highest quantity of $43.56 \pm 0.02 \%$ with fat of $5.92 \pm 0.42 \%$ as the least. The minerals present in the sample are shown in Table 2 with potassium having the highest concentration $(874.11 \pm 0.02 \mathrm{mg} / 100 \mathrm{~g})$, follows by phosphorus of $292.85 \pm 0.04 \mathrm{mg} / 100 \mathrm{~g}$ and manganese as the least value $(1.11 \pm 0.01 \mathrm{mg} / 100 \mathrm{~g})$

Table 3 shows the fatty acids composition of the seed with linoleic acid having the highest content, caprylic acid, capric acid, arachidic acid and arachidonic acid having the least content. Also, the amino acid composition of the seed is shows in Table 4 with glutamate having the highest concentration of $10.15 \pm 0.01 \mathrm{~g} / 100 \mathrm{~g}$ of protein and histidine having the least concentration of $1.84 \pm 0.02 \mathrm{~g} / 100 \mathrm{~g}$ of protein

\section{Discussion}

The proximate analysis of Leea guineensis seed (Table 1) shows that it has high protein content, comparable to other rich foods such as cowpeas, melon, pumpkin, chick beans and lima beans $[6,3,31]$, which implies that Leea guineensis seed can serve as a better source of protein alongside with its high levels of indispensable (essential) amino acids (Table 4). This function mainly in the supply of adequate amount of required amino acids, its deficiency causes growth retardation, muscle wasting (which is one of the characteristic of diabetes mellitus patient), oedema, abnormal swelling of the belly etc[19,31]. The seed's crude fibre content was significantly higher than those reported in almond nut $(7.23 \pm 0.05 \%)$ and legumes $(5-6 \%)[5,3,31]$. Fibre plays an important role in the maintenance of internal distention for a normal peristaltic movement of the intestinal tract [6,31]. It also playing an important role in preventing colon cancer, constipation, decreases the absorption of cholesterol from the gut (which it useful in prevention cardiovascular disease) in addition to delaying the digestion and conversion of starch to simple sugars, an important factor in the management of diabetes $[18,2,7,23,31]$. Dietary fibre also functions in the protection against colorectal cancer and obesity [11,31]. The highest carbohydrate content of the seed if digestible can serve as a source of energy. The lower lipid content of Leea guinaesis seeds, compared to velvet beans seed of $14.52 \pm 0.05 \%[6,31]$, would probably makes it useful ingredient for both poultry and livestock, because high fat content in the feed ingredients would cause difficulty in mixing the feed and could also predispose such feed to oxidative rancidity $[18,4,31]$. The lower moisture content indicates that the seed can be stored for long period without spoilage. In addition, the ash content gives an indication of the presence of macro and micro elements (Table 2) in the samples.

Leea guinaesis seeds shows the present of both micro and macro minerals (Table 2), which normally serve as a cofactors for several physiologic (e.g. in glycolysis, gluconeogensis, krebs cycle etc.) and metabolic functions (21). The levels of the most minerals observed in seeds were significantly different from those reported in

Table 1: Proximate composition of Leea guineensis seed (\%)

\begin{tabular}{|l|l|}
\hline Parameters & Composition \\
\hline Crude Protein & $22.30 \pm 0.45$ \\
\hline Crude Fiber & $14.38 \pm 1.20$ \\
\hline Ash & $6.96 \pm 0.16$ \\
\hline Moisture content & $6.88 \pm 0.20$ \\
\hline Fat & $5.92 \pm 0.42$ \\
\hline Carbohydrate (by difference) & $43.56 \pm 0.1$ \\
\hline Each value is a mean of three determinations \pm SEM
\end{tabular}


Table 2: Mineral content of Leea guineensis seed (mg/100g)

\begin{tabular}{|l|l|}
\hline Minerals & Amount \\
\hline Iron & $9.48 \pm 0.02$ \\
\hline Copper & $1.31 \pm 0.01$ \\
\hline Manganese & $1.11 \pm 0.01$ \\
\hline Magnesium & $147.09 \pm 0.03$ \\
\hline Potassium & $874.11 \pm 0.02$ \\
\hline Phosphorus & $292.85 \pm 0.04$ \\
\hline
\end{tabular}

Each value is a mean of three determinations \pm SEM

Table 3: Fatty acid composition of Leea guineensis seeds seed (\%)

\begin{tabular}{|l|l|}
\hline Fatty acids & Amount \\
\hline Caprylic acid & $0.02 \pm 0.01$ \\
\hline Capric acid & $0.02 \pm 0.03$ \\
\hline Lauric acid & $0.07 \pm 0.01$ \\
\hline Myristic acid & $0.11 \pm 0.01$ \\
\hline Palmitic acid & $14.84 \pm 0.02$ \\
\hline Palmitoleic acid & $0.34 \pm 0.03$ \\
\hline Margaric acid & $0.02 \pm 0.01$ \\
\hline Stearic acid & $3.75 \pm 0.02$ \\
\hline Oleic acid & $31.05 \pm 0.03$ \\
\hline Linoleic acid & $43.11 \pm 0.04$ \\
\hline Linolenic acid & $5.97 \pm 0.01$ \\
\hline Arachidic acid & $0.02 \pm 0.01$ \\
\hline Arachidonic acid & $0.02 \pm 0.01$ \\
\hline Behenic acid & $0.24 \pm 0.02$ \\
\hline Erucic acid & $0.11 \pm 0.03$ \\
\hline Lignoceric acid & $0.43 \pm 0.02$ \\
\hline Each val 2 集
\end{tabular}

Each value is a mean of three determinations \pm SEM

Table 4: Amino composition of Leea guineensis seeds seed (mg/100protein)

\begin{tabular}{|l|l|l|}
\hline Amino acids & Leea guineensis seed & FAO/WHO (1990) \\
\hline Glycine & $4.19 \pm 0.01$ & 2.2 \\
\hline Alanine & $6.34 \pm 0.02$ & 6.1 \\
\hline Serine & $7.37 \pm 0.02$ & 7.7 \\
\hline Proline & $7.57 \pm 0.01$ & 10.7 \\
\hline Valine & $4.84 \pm 0.02$ & 5.0 \\
\hline Threonine & $3.52 \pm 0.01$ & 3.4 \\
\hline Isoleucine & $3.58 \pm 0.03$ & 2.8 \\
\hline Leucine & $6.23 \pm 0.01$ & 6.6 \\
\hline Aspartate & $6.92 \pm 0.03$ & 7.7 \\
\hline Lysine & $1.99 \pm 0.01$ & 5.8 \\
\hline Methionine & $3.69 \pm 0.02$ & 2.5 \\
\hline Glutamate & $10.15 \pm 0.01$ & 14.7 \\
\hline Phenylalanine & $2.91 \pm 0.01$ & 6.30 \\
\hline Histidine & $1.84 \pm 0.02$ & 2.5 \\
\hline Arginine & $9.12 \pm 0.01$ & 5.2 \\
\hline Tyrosine & $4.35 \pm 0.01$ & 1.10 \\
\hline Cystine & $2.24 \pm 0.02$ & 3.0 \\
\hline
\end{tabular}

Each value is a mean of three determinations \pm SEM 
velvet beans seeds [6,31]. Magnesium, manganese and phosphorous are very important minerals in bone and teeth development. In addition manganese is a cofactor of hydrolase, decarboxylase and transferase enzymes, glycoprotein and proteoglycan synthesis[19]. Iron is very crucial in haemoglobin and cytochromes, and is normally be transported as transferring, stored as ferritin or hemosiderin[19]. Deficiency of iron can lead to anaemia[21]. Copper plays a crucial role in iron absorption [19], also it is a constituent of oxidase enzymes (e.g. cytochrome c oxidase etc.) and is being transported by albumin bound to ceruloplasmin. In addition, presence of antioxidant minerals like copper, manganese and iron indicates that the sample will be a good source of antioxidants with protection of the human body against oxidative damage of biological membrane due to the presence of free radicals [15] for example in diabetes mellitus and its secondary symptoms [32].

Also, the fatty acid compositions of ether extract of Leea guineensis seed are shown in Table 3. The present of caprylic acid in the sample though in trace amount gives an indication that the samples can be very useful in the commercially production of esters used in perfume and in the manufacture of dyes [31]. Caprylic acid is also used in the treatment of some bacterial infections. This may due to its relatively short chain length, with potential of penetrating fatty cell wall membranes; hence it is effect in combating certain lipid-coated bacteria, such as Staphylococcus aureus and various species of Streptococcus [20,31]. Trace amount of decanoic acid or capric acid was being observed in the sample, which is a saturated fatty acid, functions in manufacturing of esters for artificial fruit flavors and perfumes. Also, as an intermediate in chemical syntheses, it is used in organic synthesis and industrially in the manufacture of perfumes, lubricants, greases, rubber, dyes, plastics, food additives and pharmaceuticals $[9,31]$.

Lauric acid present in Leea guineensis seed, is the main fatty acid in coconut and palm kernel oils, and is believed to have antimicrobial properties $[16,22,10]$. This is also found in human milk $(5.8 \%$ of total fat), cow milk (2.2\%), and goat milk (4.5\%), which is can undergo $\beta$-oxidation to produce energy, which may be stored in adipose tissues [21]. Myristic acid or tetradecanoic acid is a common saturated fatty acid used in cosmetic. Palmitic acid is one of the most common saturated fatty acids found in animals and plants tissues. It is also the first fatty acid produced during lipogenesiss (fatty acid synthesis) and from which longer fatty acids can be produced $[19,18]$. Palmitoleic acid, or hexadecenoic acid, is an omega-7 monounsaturated fatty acid, a common constituent of the glycerides of human adipose tissue. Although, it is synthesize from palmitic acid by the action of the enzyme delta- 9 desaturase. It plays an important role in increasing insulin sensitivity by suppressing inflammation, as well as inhibiting the destruction of insulin-secreting pancreatic beta cells, which make it useful for a diabetic patient (especially for type 2 diabetes mellitus) [31]. Leea guineensis seed also has stearic acid which is a very useful ingredient in dietary supplements $[28,29]$. Oleic acid is a fatty acid that occurs naturally in various animal and vegetable fats and oils. It is also a monounsaturated fat, which has been associated with decreased low-density lipoprotein (LDL) cholesterol (bad cholesterol), and possibly increased high-density lipoprotein (HDL) cholesterol (good cholesterol) [26]. Linoleic acid and linolenic acid are the most important essential fatty acids unsaturated omega- 6 fatty acid, is a polyunsaturated fatty acid used in the biosynthesis of arachidonic acid (AA) and thus some prostaglandins [21]. They are required for the growth and cell maintenance. Furthermore, the present of oleic and linoleic couples with arachidonic acids in the sample may make it highly useful in preventing coronary heart diseases [33]. In addition, oleic acid increases insulin secretion in the presence of the inflammatory cytokine TNF- $\alpha$. The mechanisms of the anti-diabetogenic action of oleic acid are very likely multifaceted [34], while arachidonic acid is effective in preventing alloxan-induced toxicity to beta cells in vivo, the ability of arachidonic acid to prevent the development of diabetes induced by alloxan may be due to decreased production of free radicals and lipid peroxides [35]

Dietary behenic acid (22:0) is poorly absorbed, because of its low bioavailability compared with other fatty acids and because of its very long chain length, the effect of dietary behenic acid (behenate) on serum lipid concentrations in humans is assumed to be neutral[30,31]. The presence of erucic acid in the sample a monounsaturated omega- 9 fatty acid, make it useful in as a precursor to bio-diesel fuel $[9,31]$.

The amino acid profiles of Leea guineensis seed (Table 4) shows that it has seventeen amino acids; out of which nine were indispensable with arginine having the highest concentration. The seventeen amino acids present in Leea guineensis seed were also reportedly present in velvet beans seeds [6]. The indispensable amino acids (lysine, histidine, arginine, threonine, valine, methionine, isoleucine, leucine, and phenylalanine) are within FAO/ WHO [12] reference values for daily intake. These amino acids serve as raw materials for the synthesis of many other cellular products, including hormones (e.g. insulin), enzymes and pigments. They have also been reported in reducing the effects of free radicals generation in alloxan-induced diabetes rats [36] In addition, several of these amino acids are key intermediates in cellular metabolism [19]. The present study indicates that seed can serve as a source of indispensable amino acids for consumers. Also, the absence of tryptophan as the tenth indispensable (essential) amino acid could be that it was destroyed by hydrolysis. It has been reported by $[27,31]$ that hydrolysis procedure either destroys or chemically modifies the asparagines, glutamine and tryptophan residues in protein. Asparagine and glutamine are converted to their corresponding acids (aspartic and glutamic acids). This may also responsible for the highest concentration of glutamate in the sample, which plays an important role in neurotransmitter and is important for learning and memory [24] while tryptophan may has been completely destroyed [18].

\section{Conclusion}

The results of this study demonstrate the potentials of Leea guineensis seed as a rich source of essential nutrients especially protein, fibers, essential amino acids, antioxidant minerals and unsaturated fatty acids which are required in the diets of both man and livestock animals. Also it may be useful in the management of diabetes mellitus.

\section{References}

[1]. AOAC (1990). In official Methods of Analysis Association of Official Analytical Chemist, (15 ${ }^{\text {th }}$ Edition), Washington, D.C.

[2]. Ahmed, J.I. (1995) Health and dietary fiber. Nutrition Food Science. 1:1822

[3]. Anonymous, (1972) Tropical legumes: Resources future. National Academic of Science Washington, D.C., Pp:24

[4]. Atteh, J.O. (2002). Principles and Practice of livestock feed manufacturing. Adlek Printers, Ilorin, Nigeria. Pp.37

[5]. Aremu, M.O., Olaofe, O., Akintayo, T.E. (2006). Comparative study on the chemical and amino acid composition of some Nigerian underutilized legume flours. Pak. J. Nut., 5:34-38 
[6]. Balogun, I.O., Olatidoye, O.P. (2012). Chemical Composition and Nutritional Evaluation of velvet beans seeds for domestic consumption and industrial utilization in Nigeria. Pakistan Journal of Nutrition 11(2): 116-122

[7]. Bingham, S.A., Day, N.E., Luben, R., Ferrari, P., Slimani, N., Norat, T., Clavel-Chapelon, F., Kesse, E., Nieters, A., Boeing, H., Tjonneland, A., Overvad, K., Martinez, C., Dorronsoro, M., Gonzalez, C.A., Key, T.J., Trichopoulou, A., Nasaka, A., Vineis, P., Tumino, R., Krogh, V., Bueno-demesquita, H.B., Peeters, P.H., Berglund, G., Hallmans, G., Lund, E., Skeie, G., Kaaks, R., Riboli, E. (2003). Dietary fibre in food and protection against colorectal cancer in the European Perspective Investigation into Cancer and Nutrition (EIPC): An observational study. Lancet 361:1496-1501

[8]. Danesi, R., Pasqualetti, G., Giovannetti, E., Del Tacca, M. (2007). The role of pharmacogenetics in adjuvant treatment of non-small cell lung cancer, J. Thorac. Oncol., 2(5): S 27-30.

[9]. David, J., Anneken, S. B., Christoph, R., Fieg, G., Steinberner, U., Westfechtel, A. (2006). "Fatty Acids" in Ullmann's Encyclopedia of Industrial Chemistry, Wiley-VCH, Weinheim.

[10]. Dawson, P.L., Carl, G.D., Acton, J.C., Han, I.Y. (2002). Effect of lauric acid and nisin-impregnated soy-based films on the growth of Listeria monocytogenes on turkey bologa. Poultry Science 81(5):721-726

[11]. Eleazu, C.O. and Okafor, P.N. (2012). Antioxidant effect of unripe plantain (Musa paradisiacae) on oxidative stress in alloxan-induced diabetic rabbits

[12]. FAO/WHO (1990). Protein quality evaluation, In: Report of A joint FAO/ WHO Expert Consultations FAO of the United Nations, Rome. Pp. 40

[13]. Falodun, A.O., Okunrobo, L.O., Agbo, L.O. (2007). Evaluation of the antiedematogenic activity of the aqueous extract of Leea guineensis. African Journal of Biotechnology. Vol. 6(9):1151-1153

[14]. Gills, L.S. (1992). Ethnomedicinal uses of plants in Nigeria. University of Benin Press, Benin City, Edo State; Nigeria. Pp. 65-75

[15]. Hassan, A.A., Abd El-Razek, F.H. (2011). Nutritional value and hypoglycemic effect of prickly catus pear fruit juice in alloxan-induced diabetic rats. Australian Journal of basic and applied sciences.5 (10): 356-377.

[16]. Hoffman, K.L., Han, I.Y., Dawson, P.L. (2001). Antimicrobial effects of corn zein films impregnated with nisin, lauric acid and EDTA. Journal of Food Protein 64(6):885-9

[17]. Hutchinson, A.J.J.M., Daziel, R.W., Keay, J., Heppar, J. (1968). Flora of West Tropical Africa and its Pharmaceutical Potentials. Mediconsult. Vol. $31: 28-16$

[18]. Muhammad, N.O., Ajiboye, B.O. (2010). Nutrients composition of Rana galamensis. African Journal of Food Science and Technology Vol. 1(1) Pp. 027-30

[19]. Murray, R.K., Granner, D.K., Mayer, P.A., Rodwell, V.W.(2000) In: Harper's Biochemistry. A Lange Medical Book, $20^{\text {th }}$ Edition. McGraw-Hill

[20]. Nair, M.K., Joy, J., Vasudevan, P., Hinckley, L., Hoagland, T.A., Venkitanarayanan, K.S. (2005). "Antibacterial effect of caprylic acid and monocaprylin on major bacterial mastitis pathogens". J Dairy Sci 88 (10): 3488-95.

[21]. Nelson, D.C., Cox, M.M. (2005). Lehninger Principles of Biochemistry (4th edition). W.H. freeman and Co., New York
[22]. Outtar, B., Simard, R.E., Piett, G., Begin, A., Holley, R.A. (2000). Inhibition of surface spoilage bacteria in processed meats by application of antimicrobial films prepared with chitosan. International Journal of Food Microbiology. 62(1-2): 139-48

[23]. Park, Y., Hunter, D.J., Spiegelman, D., Bergkvist, L., Bernino, F., Van De Brandt, P.A., Buring, J.E., Colditz, G.A., Freudenheim, J.L., Fuch, C.S., Giovannucci, E., Goldbohm, R.A., Graham, S., Harnack, L., Hartman, A.M., Jacobs, D.R., Kato, I., Krogh, V., Leitzmann, M.F.,McCullough, M.L.,Miller, A.B., Pietinen, P., Rohan, T.E., Schatzkin, A., Willet, W.C., Wolk, A, Zeleniuch-Jacquotte, A., Zhang, S.M., Smith-Warner, S.A. (2005). Dietary fiber intake and risk of colorectal cancer: a pooled analysis prospective cohort studies. JAMA, 294:2849-2857

[24]. Robert, S. (2005). "Biology and Human Behavior: The Neurological Origins of Individuality, 2nd edition". The Teaching Company. Pp.19-20.

[25]. Stafford, G.I., Pedersen, M.E., Van Staden, J., Jäger, A.K. (2008). Review on plants with CNSeffects used in traditional South African medicine against mental diseases. Journal of Ethnopharmacology 119: 513-537.

[26]. Thomas, A. (2000). "Fats and Fatty Oils". Ullmann's Encyclopedia of Industrial Chemistry

[27]. Wilson, K., Walker, J. (2000). Principles and Techniques of practical Biochemistry. Cambridge University Press, $5^{\text {th }}$ Edition, Uk

[28]. Wootthikanokkhan, J., Tunjougnawin, P. (2002). Investigation of the effect of mixing schemes on cross-link distribution and tensile properties of natural-acrylic rubber bends. Polymer Testing 22(3): 305-312

[29]. Zhi-Hong, Y, Miyahara, H., Hatanaka, A. (2011). Chronic administration of palmitoleic acid reduces insulin resistance and hepatic lipid accumulation in KK-Ay Mice with genetic type 2 diabetes. Lipids in Health and Disease. 10:120

[30]. Cater, N.B., Denke, M.A (2001). Behenic acid is a cholesterol-raising saturated fatty acid in humans. Am J Clin Nutr. 73(1):41-4

[31]. Ajiboye, B.O., Ibukun, E. O., Edobor, G., Ojo, A.O. and Onikanni, S. A (2013). Chemical composition of Senecio leaf. Scientific journal of biological sciences. 2(8): 152-159

[32]. Dallatu, M.K., Anaja, P.O., Bilbis, L. S., Mojiminiyi, F. B. O., Mohammed, .A and Tanko, Y (2010). Haematological and Antioxidant Properties of Alloxan-Induced Diabetes Rats Supplemented with Antioxidant Micronutrients. Nigerian Journal of Basic and Applied Science. 18(1):106-111

[33]. Bucher, H.C., Hengstler, P., Schindler, C. and Meier, G. (2002). N-3 polyunsaturated fatty acids in coronary heart disease: a metaanalysis of randomized controlled trials. Am. J. Med., 112: 298304.

[34]. Rahimi, P., Kabiri, N., Asgary, S. and Setorki, M. (2011). Anti-diabetic effects of walnut oil on alloxan induced diabetic rats.African journal of pharmacy and pharmacology. Vol.5(24): 2655-2661

[35]. Das, U.N. (2001). Nutritional factors in the pathobiology of human essential hypertension. 17: 337-346.

[36]. El-Missiry, M.A., Othman, M.A. and Amer, M. A. (2004). L-Arginine Ameliorates Oxidative Stres in Alloxan-induced Experimental Diabetes Mellitus. J. Appl. Toxicol. 24, 93-97 